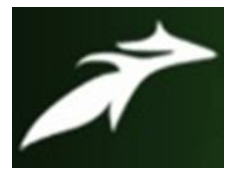

Pooja Goswami et al, International Journal of Advances in Agricultural Science and Technology,

Vol.8 Issue.7, July-2021, pg. 48-54

\title{
Credibility of Different Agricultural Information Sources Utilized by Farm Women of Uttarakhand
}

\author{
Pooja Goswami ${ }^{1}$; Dr. Kiran Rana ${ }^{2}$ \\ ${ }^{1}$ MSc. Scholar, pujagoswami0@gmail.com \\ ${ }^{2}$ Assistant Professor, kiranagricommunication@ gmail.com \\ DOI: 10.47856/ijaast.2021.v08i7.006
}

\begin{abstract}
Credibility of agricultural information sources affects the adoption of new or improved agricultural practices by farmers. Credibility refers to perceived trustworthiness accorded to a source by its audience at any given time and situation. Therefore, Credible sources of agriculture information play major role in diffusion of agriculture innovations. This study was carried out in Nainital district of Uttarakhand state with specific objective to explore the relative credibility of information sources as accorded by the farm women of the region. A sample of 120 farm women was selected by PPS (Probability proportional to size) sampling method. The agriculture information sources were categorized into three broad heads namely personal localite, personal cosmopolite and mass media. It was found that majority $(62.5 \%)$ of respondents had 'medium' credibility towards agriculture information sources followed by 20 per cent having low credibility and only 17.5 per cent had high credibility to different agriculture information sources. It was further found that family members, KVK officials and newspaper were considered as the most credible sources of agricultural information among personal localite, personal cosmopolite and mass media sources.
\end{abstract}

Keywords: Credibility; Sources; Agriculture information; Mass media; Cosmopolite

\section{Introduction}

In rural Uttarakhand, women contribute up to 90 per cent of the total work force in agriculture and animal care. The work participation rate of women has been constantly increasing to a large extent than men in the state over the past few years. Sharma and Kriti (2012) reported that the women in the state devote as much as 62.17 per cent of time for outdoor activities, 21.11 per cent for indoor activities and 8.72 per cent for recreational activities.

Agricultural Information is an important factor that interacts with other production factors. Information supplied by extension, research, education and agricultural organizations help women farmers make better decisions. Information dissemination is a subject of considerable importance for hill farm women who commonly suffer from isolation and have difficulties in communicating their priorities to decision makers. Also, Information unevenness at farm level has been recognized as one of the main explanations for low agriculture productivity and production efficiency. Thus, an improved and strengthened agricultural extension infrastructure is needed to all the levels of supply chain and it will provide push towards higher productivity additionally. According to economic reforms in the country each and every sector has changed its strategies in 


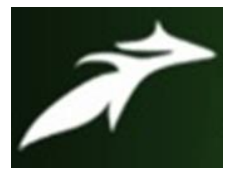

Pooja Goswami et al, International Journal of Advances in Agricultural Science and Technology,

Vol.8 Issue.7, July-2021, pg. 48-54

ISSN: 2348-1358

Impact Factor: 6.057

NAAS Rating: 3.77

view of global competition. The credibility of information sources and channels affects the extent of adoption of different improved agricultural practices by the farmers. The source preference and its credibility may differ at different stages of innovation process depending upon the socio-economic, educational and other personal characteristics of farmers (Patel, 2011). The credibility refers to the perceived trustworthiness accorded to a source by its audience at any given time. Therefore, sources and channels of agriculture information play major role in diffusion of agriculture innovation.

\section{Methodology}

The present study was conducted in kumaun region of Uttarakhand state. Nainital district was selected by simple random sampling method. Ramgarh block of this district was selected through simple random sampling by chit method. Four villages were selected from the Ramgarh block. Respondents were selected by using PPS (Probability Proportional to size) sampling method. Thus, a total of 120 respondents were selected for the study. The researcher collected data through structured schedule employing personal interview technique. Collected data were tabulated, analyzed and interpreted in the light of the objectives set for the study.

For measuring the degree of credibility of different sources and channels of agricultural information credibility index developed by Gunawardana (2005) was used after slight modification as suggested by the experts. The responses of the respondents were recorded on a three point continuum namely ,highly credible ${ }^{\text {ee }}$ ' credible' and 'not credible' with a score of 3,2 and 1, respectively.

The degree of credibility score of a respondent was worked out by summing the credibility score obtained by that respondent in all the sources of agriculture information. The mean percent scores of each source were worked out and then all the sources were given the rank according to their degree of credibility.

\section{Results and Discussion}

Credibility of a particular agricultural information sources can be defined as the degree to which a source or channel is perceived as trustworthy and competent by the receiver. The different sources of agriculture information are one of the most important elements of communication process and their effectiveness largely depends upon their credibility as perceived by the person. Hence, it is necessary to know the credibility of different sources of agriculture information for transfer of any new technology or improved practice. Credibility of different sources of agriculture information was therefore studied and results are presented as followed.

- Distribution of farm women according to their extent of credibility to different sources of agriculture information

- Credibility of different personal localite sources of agriculture information by farm women

- Credibility of different personal cosmopolite sources of agriculture information by farm women

- Credibility of different personal mass media sources of agriculture information by farm women

Distribution of farm women, according to the extent of their credibility to different sources of agriculture information.

The Credibility of particular farm woman was calculated by summing the scores obtained by that particular farmer in all the three components of Credibility which personal localite sources, personal cosmopolite sources 


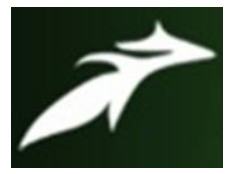

Pooja Goswami et al, International Journal of Advances in Agricultural Science and Technology,

Vol.8 Issue.7, July-2021, pg. 48-54

ISSN: 2348-1358

Impact Factor: 6.057

NAAS Rating: 3.77

and mass media sources. Then the farm women were categorized into three different levels of credibility namely, low, medium and high.

Table 1 indicated that majority (62.5\%) of respondents had 'medium' credibility towards agriculture information sources followed by 20 per cent with 'low' credibility and only 17.5 per cent had 'high' credibility towards agriculture information sources.

\section{Credibility of different personal localite sources of agriculture information by farm women.}

It can be seen from table 2 that majority (61.66\%) of the respondents perceived family members as the highly credible personal localite source of information followed by Neighbors 54 per cent and friends 50 per cent. Likewise maximum $(65.83 \%)$ number of respondents perceived progressive farmers as the credible source of agriculture information followed by agriculture graduates and opinion leader with 65 per cent and 60 per cents of respondents respectively.

\section{Credibility of different personal cosmopolite sources of agriculture information by farm women.}

From Table 3 it is clear that KVK officials are perceived as the highly credible personal cosmopolite source of information by maximum (45\%) number of the respondents, followed by village level works with 34.16 per cent. Likewise NGO personnel and agriculture officer are perceived as the credible source of information by 45.83 per cent each, of the respondents. Further, input supplier (39.16\%) followed by Co. operative officials with 38.33 per cent of respondents is perceived as the least credible personal cosmopolite source of information.

\section{Credibility of different personal mass media sources of agriculture information by farm women.}

It can be seen from table 4 that majority of the respondents perceived Newspaper as both highly credible (44.16\%) and credible (50.83\%) mass media source of information. Further, it can also be seen that landline is perceived as the least credible source of information by maximum (82.5\%) number of the respondents.

Table 3.1. Distribution of respondents according to their of credibility of different sources and channels of agriculture information

\begin{tabular}{|l|c|c|}
\hline Degree of credibility & \multicolumn{2}{|c|}{ Farm women } \\
\cline { 2 - 3 } & Frequency & Percentage \\
\hline Low credibility & 24 & 20 \\
\hline
\end{tabular}




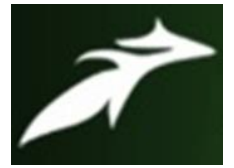

Pooja Goswami et al, International Journal of Advances in Agricultural Science and Technology, Vol.8 Issue.7, July-2021, pg. 48-54

ISSN: 2348-1358

Impact Factor: 6.057

NAAS Rating: 3.77

\begin{tabular}{|l|c|c|}
\hline Medium credibility & 75 & 62.5 \\
\hline High credibility & 21 & 17.5 \\
\hline
\end{tabular}

Table 3.2. Distribution of respondents according to credibility of Personal localite sources of information

$(\mathbf{n}=\mathbf{1 2 0})$

\begin{tabular}{|c|c|c|c|c|c|c|c|c|c|}
\hline \multirow[t]{2}{*}{ Sl. No. } & \multirow[t]{2}{*}{ Information sources } & \multicolumn{2}{|c|}{ Highly credible } & \multicolumn{2}{|c|}{ Credible } & \multicolumn{2}{|c|}{ Not credible } & \multirow[b]{2}{*}{$\begin{array}{l}\text { WM } \\
\text { S }\end{array}$} & \multirow[b]{2}{*}{ Rank } \\
\hline & & Freq. & $\begin{array}{l}\text { percentag } \\
\text { e }\end{array}$ & Freq. & $\begin{array}{l}\text { percenta } \\
\text { ge }\end{array}$ & Freq. & $\begin{array}{l}\text { percentag } \\
\text { e }\end{array}$ & & \\
\hline 1. & Progressive farmers & 30 & 25 & 79 & 65.83 & 11 & 9.16 & 2.15 & VII \\
\hline 2. & Family members & 74 & 61.66 & 39 & 32.5 & 7 & 5.83 & 2.55 & $\mathbf{I}$ \\
\hline 3. & Friends & 50 & 41.66 & 54 & 45 & 16 & 13.33 & 2.28 & II \\
\hline 4. & Opinion leader & 35 & 29.16 & 72 & 60 & 13 & 10.83 & 2.18 & VI \\
\hline 5. & Neighbours & 54 & 45 & 40 & 33.33 & 26 & 21.66 & 2.23 & III \\
\hline 6. & Relatives & 48 & 40 & 51 & 42.5 & 21 & 17.5 & 2.22 & IV \\
\hline 7. & Agriculture graduates & 26 & 21.66 & 78 & 65 & 16 & 13.33 & 2.08 & VIII \\
\hline 8. & Panchayat members & 40 & 33.33 & 67 & 55.83 & 13 & 10.83 & 2.22 & IV \\
\hline
\end{tabular}

- Multiple response table 


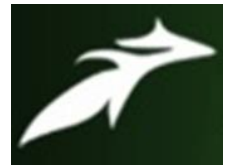

Pooja Goswami et al, International Journal of Advances in Agricultural Science and Technology,

Vol.8 Issue.7, July-2021, pg. 48-54

ISSN: 2348-1358

Impact Factor: 6.057

NAAS Rating: 3.77

Table 3.3. Distribution of respondents according to credibility of Personal cosmopolite sources of information

$(\mathbf{n}=120)$

\begin{tabular}{|c|c|c|c|c|c|c|c|c|c|}
\hline \multirow[t]{2}{*}{ Sl. No. } & \multirow[t]{2}{*}{ Information sources } & \multicolumn{2}{|c|}{ Highly credible } & \multicolumn{2}{|c|}{ Credible } & \multicolumn{2}{|c|}{ Not credible } & \multirow[b]{2}{*}{ WMS } & \multirow[b]{2}{*}{ Rank } \\
\hline & & Freq. & $\begin{array}{l}\text { percentag } \\
\text { e }\end{array}$ & Freq. & $\begin{array}{l}\text { percentag } \\
\text { e }\end{array}$ & Freq. & $\begin{array}{l}\text { percentag } \\
\text { e }\end{array}$ & & \\
\hline 1. & $\begin{array}{l}\text { Agriculture Research } \\
\text { scientist }\end{array}$ & 30 & 25 & 54 & 45 & 36 & 30 & 1.95 & $\mathbf{V}$ \\
\hline 2. & NGOs personnel & 24 & 20 & 55 & 45.83 & 41 & 34.16 & $\mathbf{1 . 7 5}$ & $\mathbf{X}$ \\
\hline 3. & Agriculture officers & 36 & 30 & 55 & 45.83 & 29 & 24.16 & 2.05 & III \\
\hline 4. & Private agencies & 22 & 18.33 & 66 & 55 & 32 & 26.66 & 1.91 & VII \\
\hline 5. & KVK officials & 54 & 45 & 48 & 31.66 & 18 & 15 & 2.3 & $\mathbf{I}$ \\
\hline 6. & Village level workers & 41 & 34.16 & 51 & 42.5 & 28 & 23.33 & 2.1 & II \\
\hline 7. & Co. operative officials & 38 & 31.66 & 36 & 30 & 46 & 38.33 & 1.93 & VI \\
\hline 8. & Farmer's fairs & 39 & 32.5 & 47 & 39.16 & 34 & 28.33 & 2.04 & IV \\
\hline 9. & Input supplier & 19 & 15.83 & 54 & 45 & 47 & 39.16 & 1.76 & IX \\
\hline 10 & Shopkeepers & 32 & 26.66 & 44 & 36.66 & 44 & 36.66 & 1.9 & VIII \\
\hline
\end{tabular}

- Multiple response table 


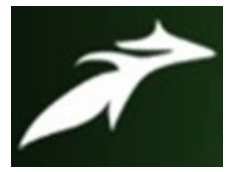

Pooja Goswami et al, International Journal of Advances in Agricultural Science and Technology,

Vol.8 Issue.7, July-2021, pg. 48-54

ISSN: 2348-1358

Impact Factor: 6.057

NAAS Rating: 3.77

Table 4.4. Distribution of respondents according to credibility of mass media source of information

$(\mathbf{n}=\mathbf{1 2 0})$

\begin{tabular}{|c|c|c|c|c|c|c|c|c|c|}
\hline \multirow{2}{*}{$\begin{array}{l}\text { Sl. } \\
\text { No. }\end{array}$} & \multirow[t]{2}{*}{ Information sources } & \multicolumn{2}{|c|}{ Highly credible } & \multicolumn{2}{|c|}{ Credible } & \multicolumn{2}{|c|}{ Not credible } & \multirow[b]{2}{*}{ WMS } & \multirow[b]{2}{*}{ Rank } \\
\hline & & Freq. & percentage & Freq. & percentage & Freq. & percentage & & \\
\hline 1. & Radio & 38 & 31.66 & 54 & 45 & 28 & 23.33 & 2.08 & II \\
\hline 2. & Television/ film shows & 42 & 35 & 30 & 25 & 48 & 40 & 1.95 & $\mathbf{V}$ \\
\hline 3. & News paper & 53 & 44.16 & 61 & 50.83 & 6 & 5 & 2.39 & I \\
\hline 4. & $\begin{array}{l}\text { Farm journals/ } \\
\text { magazines }\end{array}$ & 40 & 33.33 & 45 & 37.5 & 35 & 29.16 & 2.04 & III \\
\hline 5. & Computer (Internet ) & 35 & 29.16 & 20 & 16.66 & 65 & 54.16 & 1.75 & VII \\
\hline 6. & Cell phone & 41 & 34.16 & 38 & 31.66 & 41 & 34.16 & 2 & IV \\
\hline 7. & Landline & 16 & 13.33 & 5 & 4.16 & 99 & 82.5 & 1.3 & VIII \\
\hline 8. & $\begin{array}{l}\text { Smartphone with } \\
\text { internet }\end{array}$ & 49 & 40.83 & 37 & 30.83 & 34 & 28.33 & 1.81 & VI \\
\hline
\end{tabular}

- Multiple response table

4. Conclusion

The present study concluded that Maximum number (62.5\%) of respondents had 'medium' credibility towards agriculture information sources followed by 20 per cent with 'low' credibility and only 17.5 per cent had 'high' credibility towards agriculture information sources.

Along with this, family members, friends and neighbors were found to be most credible sources of information among personal localite sources for the farm women. This may be due to the accessibility and easy approach to these sources. This study also revealed that KVK officials, Village level workers and Agriculture officers had high level of credibility among the personal cosmopolite sources for the farm women. Further, it was also found that Newspaper was the most credible mass media sources of information followed by Radio and Farm journals/magazines. 


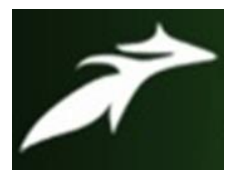

Pooja Goswami et al, International Journal of Advances in Agricultural Science and Technology,

Vol.8 Issue.7, July-2021, pg. 48-54

ISSN: 2348-1358

Impact Factor: 6.057

NAAS Rating: 3.77

\section{References}

[1]. Dhayal, B.L. and Bochalya, B.C. (2015). Credibility of different sources and channels of agriculture information as perceived by the ber growers. Agric. Update, 10(1): 17-22.

[2]. Gunawardana, A.M.A.P.G. (2005). Communication behaviour of farmers on improved farm practices on Udaipur district of Rajasthan. M.Sc. Thesis, Maharana Pratap University of Agriculture and Technology, Udaipur (RAJASTHAN) INDIA.

[3]. Patel, S. (2011). Technological gap in cotton cultivation. M.Sc. (Ag.) Thesis, Anand Agricultural University, Anand, GUJARAT (INDIA).

[4]. Sharma, N.B. and Prasad, N.K. 2012. "Gender and Development in the world of Work and Health. Published in Tribune". Dehradun on January 9,2011 under the title'Rural Women play crucial role in State Agriculture'.

\section{A Brief Author Biography}

Pooja Goswami- Pooja Goswami has completed her master's in "Agricultural Extension and Communication" from G.B. Pant University of Agriculture and Technology. In her dissertation topic she addressed the issues faced by women farmers of hill regions in receiving agricultural information. Currently she is working as an Assistant professor with Tula's Institute, Dehradun, Uttarakhand.

Dr. Kiran Rana- Dr. Kiran Rana is an assistant professor at G.B. Pant University of Agriculture and Technology in college of Agriculture. She has worked as a Technical Assistant in Ministry of Agriculture, Department of Agriculture \& Cooperation under the scheme of National Food Security Mission. Dr. Rana has specialization in Women Empowerment through SHGs /ICT (Information Communication Technology. She has also received several awards including Young scientist award 2018, Excellence in teaching award-2018 on the occasion of $2^{\text {nd }}$ international conference "advance in agricultural, biological and applied sciences for sustainable future (ABAS-2018)' and Emerging scientist award 2019 in recognition of outstanding work done in the field of Agriculture in national conference on "Resilience and resource management including ICT for sustainable Agriculture \& Biotechnology”. 